\title{
Effect of different degraded protein balances (OEB) on the performance of beef bulls and on digestibility and rumen fermentation in sheep ${ }^{1}$
}

\author{
L.O. FIEMS*, B.G. COTTYN, Ch.V. BOUCQUE, J.M. VANACKER AND \\ S. DE CAMPENEERE
}

Agricultural Research Centre-Ghent, Department Animal Nutrition and Husbandry, Scheldeweg 68, B-9090 Melle-Gontrode, Belgium

* Corresponding author (fax: +32-9-2525278; e-mail: rvv@ pophost.eunet.be)

Received 26 May 1998; accepted 22 February 1999

\begin{abstract}
One-hundred and twenty-five non-double-muscled Belgian Blue finishing bulls (live weight range $375-620 \mathrm{~kg}$ ) were used to investigate the effect of different levels of degraded protein balance in the rumen (OEB; $-2,-7,-16$ and $-22 \mathrm{~g} \mathrm{~kg}^{-1}$ dry matter; DM) on animal performance, with the dietary content of true protein digested in the small intestine (DVE) fixed at $80 \mathrm{~g} \mathrm{~kg}^{-1}$. Lower OEB levels significantly reduced daily liveweight gain from 1.57 to $1.39 \mathrm{~kg}$ during the first 84 days of the experiment, but not during the subsequent part. For the whole experiment, daily liveweight gain decreased from 1.40 to $1.32 \mathrm{~kg}$ but the difference was not significant. Intake of DM, DVE and net energy for fattening was not modified by OEB level, while crude protein intake was reduced and OEB lack was increased. An OEB level of $-22 \mathrm{~g}$ $\mathrm{kg}^{-1} \mathrm{DM}$ resulted in a significantly unfavourable conversion of DM and net energy during the initial months (11.3 and $11.5 \%$ compared to $\mathrm{OEB}=-2 \mathrm{~g} \mathrm{~kg}^{-1} \mathrm{DM}$, respectively). For the total period the conversion of DM and net energy was still less favourable, but the differences were not significant. There was a nominal decrease in cold carcass weight and dressing proportion when OEB level decreased, but the effect was not significant.

The effect of different OEB levels on digestibility and rumen fermentation was investigated in a separate experiment with wethers. Apparent protein digestibility was reduced from 74.2 to $68.9 \%$ when OEB level decreased. Rumen $\mathrm{pH}$ and concentrations and molar percentages of volatile fatty acids were not altered by OEB level. Ammonia concentration was only reduced by a lower OEB level at $7 \mathrm{hr}$ after feeding.

Because of a nominal reduction in daily liveweight gain, feed efficiency, carcass weight, dressing percentage and carcass conformation with decreasing OEB level, it is advisable not

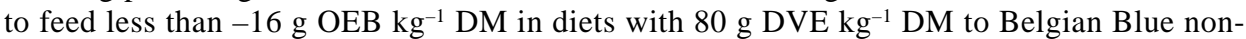
double-muscled finishing bulls from $375 \mathrm{~kg}$ onwards. This tolerable OEB lack is larger than proposed in case of protein overfeeding.
\end{abstract}

Keywords: degraded protein balance, beef bulls, performance, carcass quality, digestibility, rumen fermentation

\footnotetext{
${ }^{1}$ Communication No. 1070 of the Department.
} 


\section{Introduction}

The protein content of each feed is characterised by two values in most of the new protein evaluation systems (Anonymous, 1988; Madsen, 1985; Tamminga et al., 1994). Although differences exist in the mode of expression between the protein systems, the values are composed of the digestible true protein contributed by the rumen bypass feed protein and the microbial protein synthesised in the rumen. A certain equilibrium in the diet is desirable, meaning that the rumen protein balance (PDIN - PDIE, Anonymous, 1988; PBV, Madsen, 1985; OEB, Tamminga et al., 1994) should be close to zero in their respective systems. However, small negative values in growing cattle can be tolerated, because of the nitrogen recycling. The Dutch protein system only allows a lack of OEB (degraded protein balance in the rumen) in animals weighing more than $250 \mathrm{~kg}$, when the DVE (true protein digested in the small intestine) intake exceeds the DVE requirement. In the French protein system the lack of nitrogen available for rumen microbes is expressed per unit of energy. Based on these two protein systems, differences in minimal rumen available nitrogen may occur. According to the Dutch system the OEB lack in a $450 \mathrm{~kg}$ bull may account to $50 \mathrm{~g}$ OEB daily. If we assume a DM intake of $8.1 \mathrm{~kg}$ for $450 \mathrm{-kg}$ weighing bulls (Fiems et al., 1999) with 7.62 MJ net energy value for fattening (NEF) per kg $\mathrm{DM}$, then the tolerable OEB lack can rise to more than $100 \mathrm{~g}$, based on the French protein system. This is considerably higher than in the Dutch system. When the DVE/OEB system was introduced, Tamminga et al. (1994) stated that the influence of a negative OEB level was yet to be demonstrated. This paper deals with the effect of different OEB-values with a similar DVE content in diets for finishing beef bulls.

\section{Materials and methods}

\section{Beef production experiment}

One hundred and twenty-five non-double-muscled Belgian Blue bulls, purchased in the market, were used in three series (41, 48 and 36 bulls, respectively) over three consecutive years. After an adaptation period of approximately 2 months and at a live weight (LW) of $376 \mathrm{~kg}$, the bulls were divided into four comparable groups based on LW, age, conformation score, and LW gain during the adaptation period. Seventy-two animals, equally divided over the 4 groups, were confined in loose houses with slatted floors (6 bulls per pen). The other bulls were housed in strawbedded tie stalls. Animals were weighed on three subsequent days at the start, and on two subsequent days after 84 days and at the end of the trial after 138 to 222 days.

The diet consisted of maize silage and concentrates (65/35 on a DM-basis). They were distributed once daily, adjusting the amount offered to minimize refusals, but always with respect to the concentrate/roughage ratio. Both feeds were fed separately at the same time. The concentrates were formulated to give a similar DVE content of $80 \mathrm{~g}$ per kg dietary DM. The pre-arranged OEB levels, based on tabular values for concentrate ingredients (Anonymous, 1994) and tabular coefficients (Anonymous, 
1991) and actual analysis for maize silage, were $+2,-6,-14$ and -22 g per kg dietary DM for the respective groups. These OEB levels were maintained throughout the entire experiment. The ingredients of the concentrates are listed in Table 1. Drinking water was always available.

A jugular blood sample was taken after 61 and 145 days, only during the first series (11, 10, 10 and 10 animals, respectively), to determine blood urea nitrogen (BUN).

The animals were weighed after a feed withdrawal of $20 \mathrm{hr}$ and then slaughtered. Water was withdrawn for $16 \mathrm{hr}$ prior to slaughter. Dressing percentage was calculated and carcasses were classified according to the SEUROP-scheme (Anonymous, 1981). The 8th-rib-cut from the right carcass half was removed to estimate the carcass composition as described by Verbeke \& Van de Voorde (1978).

\section{Digestibility and rumen fermentation experiment}

The digestibility of the diets was estimated with five rumen-fistulated wethers per series, fed at maintenance level for energy, using a latin square design. The collection period lasted 10 days and was preceeded by a 14-day adaptation period. After the digestibility trial, the feeding level was increased up to ad libitum. Rumen fluid samples were taken during three consecutive days, immediately before feeding and at 3.5 and 7 hrs postprandial, starting at the 5th day after the end of the digestibility trial. Volatile fatty acids (VFA) were determined by gas chromatography on the sample taken at 3.5 hrs postprandial. Ammonia and $\mathrm{pH}$ were determined on the three samples.

\section{Chemical analyses}

Weende components of the feeds were analysed according to the EU methods. DVE and OEB-values of the feeds were estimated as described by De Boever et al. (1995). The NEF (Van Es, 1977) was calculated based on in vitro techniques (De Boever et

Table 1. Ingredients in the experimental concentrates $\left(\mathrm{kg} \mathrm{ton}^{-1}\right)$.

\begin{tabular}{|c|c|c|c|c|}
\hline & \multicolumn{4}{|c|}{ Pre-arranged dietary OEB level ( $\left.\mathrm{g} \mathrm{kg}^{-1} \mathrm{DM}\right)$} \\
\hline & +2 & -6 & -14 & -22 \\
\hline Soyabean meal & 300 & 261.5 & 257.3 & 64.7 \\
\hline Treated soyabean meal* & - & - & - & 84 \\
\hline Maizeglutenfeed & 250 & 211 & 64 & 250 \\
\hline Coconut cake & - & 46.3 & 77 & 72.3 \\
\hline Rapeseed meal & 66 & 66 & 40 & - \\
\hline Malt sprouts & 56 & - & - & - \\
\hline Barley & 134.7 & 92.5 & 73 & 42 \\
\hline Beet pulp & 16 & 147 & 312.7 & 311.3 \\
\hline Beet molasses & 60 & 60 & 60 & 60 \\
\hline Tallow & 20 & 20 & 20 & 20 \\
\hline Mineral, trace element and vitamin premix & 77.3 & 75.7 & 76 & 75.7 \\
\hline Binder (Pelletin-Mg, Zell-Lignin, Germany) & 20 & 20 & 20 & 20 \\
\hline
\end{tabular}

* Treated with formaldehyde (trade name: Rumi-S, Schouten Industries, Giessen, The Netherlands). 
Table 2. Chemical analysis and nutritive value of the feeds.

\begin{tabular}{|c|c|c|c|c|c|}
\hline \multirow[b]{2}{*}{ Dietary OEB level ( $\left.\mathrm{g} \mathrm{kg}^{-1} \mathrm{DM}\right)$} & \multicolumn{4}{|c|}{ Concentrates } & \multirow[t]{2}{*}{ Maize silage } \\
\hline & -2 & -7 & -16 & -22 & \\
\hline \multicolumn{6}{|l|}{ Chemical analysis $(\mathrm{g} / \mathrm{kg})$} \\
\hline Dry matter (DM) & 885 & 887 & 889 & 892 & 350 \\
\hline \multicolumn{6}{|l|}{ Composition of DM } \\
\hline Crude protein & 258 & 240 & 219 & 192 & 71 \\
\hline Ether extract & 46 & 48 & 44 & 48 & 29 \\
\hline Crude fibre & 73 & 88 & 107 & 108 & 194 \\
\hline Ash & 105 & 106 & 108 & 106 & 47 \\
\hline \multicolumn{6}{|l|}{ Nutritive value of DM } \\
\hline $\mathrm{NEF}(\mathrm{MJ})$ & 7.99 & 8.16 & 8.23 & 8.16 & 6.84 \\
\hline $\operatorname{DVE}(\mathrm{g})$ & 130 & 128 & 131 & 125 & 56 \\
\hline $\mathrm{OEB}(\mathrm{g})$ & 75 & 59 & 36 & 16 & -43 \\
\hline
\end{tabular}

al., 1998). The chemical composition and the nutritive value of the feeds are shown in Table 2.

The BUN was determined according to the Berthelot method (Anonymous, 1992). The method of Voigt and Steger (1967) was used for the analysis of ammonia, while the analysis of the VFA in the rumen fluid was carried out according to Supelco (Anonymous, 1997).

\section{Statistical analyses}

No significant interactions were found between OEB level, series, and housing with regard to animal performance and carcass data. However, a series effect was observed for intake and feed conversion during the second part of the experiment and the whole experiment, but this was not considered as being of main importance within the context of this experiment. Therefore, the results are presented based on a one-way analysis of variance, whereas treatment means are ranked for significance using the Newman-Keuls test. Analysis of intake and feed conversion (intake per $\mathrm{kg}$ liveweight gain) was based on means of tied animals and pen means of loose-housed bulls per series and per treatment. Also treatment effects on digestibility and rumen fermentation were estimated using a multiple analysis of variance with series and treatment as the main factors for digestibility and series, treatment and sampling day as the main factors for the fermentation characteristics. Treatment means were again ranked for significance by the Newman-Keuls test.

\section{Results}

\section{Beef production experiment}

Protein concentrations per $\mathrm{kg}$ DM of the diets averaged $-2,-7,-16$ and $-22 \mathrm{~g}$ OEB, and 135, 129, 121 and $112 \mathrm{~g}$ crude protein, respectively, whereas DVE-content only 
Table 3. Effect of dietary OEB level on liveweight gain.

\begin{tabular}{|c|c|c|c|c|c|}
\hline & \multicolumn{4}{|c|}{ Dietary OEB level ( $\left.\mathrm{g} \mathrm{kg}^{-1} \mathrm{DM}\right)$} & \multirow[t]{2}{*}{ Pooled s.e. } \\
\hline & -2 & -7 & -16 & -22 & \\
\hline Number of bulls & 32 & 31 & 31 & 31 & \\
\hline Initial weight (kg) & 376.2 & 376.4 & 376.2 & 375.8 & 28.8 \\
\hline Weight after 84 days $(\mathrm{kg})$ & 507.8 & 500.3 & 501.5 & 492.5 & 42.2 \\
\hline Final weight $(\mathrm{kg})$ & 622.7 & 613.7 & 620.5 & 607.9 & 41.7 \\
\hline Experimental days & 176.3 & 174.8 & 174.8 & 176.0 & 23.0 \\
\hline \multicolumn{6}{|l|}{ Daily gain (kg) } \\
\hline $1-84$ days & $1.57^{\mathrm{a}}$ & $1.48^{\mathrm{ab}}$ & $1.49^{\mathrm{ab}}$ & $1.39^{\mathrm{b}}$ & 0.26 \\
\hline 85 th day - end & 1.24 & 1.29 & 1.30 & 1.25 & 0.29 \\
\hline total period & 1.40 & 1.40 & 1.39 & 1.32 & 0.21 \\
\hline
\end{tabular}

ab Values without or with the same superscripts are not significantly different $(P>0.05)$.

ranged between 80 and $82 \mathrm{~g}$. During the first 84 experimental days, daily LW gain was decreased with decreasing OEB level (Table 3). However, from 85 days onward, the animals with an OEB level of -7 and -22 realized a small but nonsignificant compensatory gain, so that the overall daily LW gain was not different among groups.

There was no clear effect of the OEB level on the daily intake of DM, energy and DVE, while both crude protein and OEB intake were different among treatments (see Table 4). OEB intake per $\mathrm{kg}$ metabolic weight averaged $-0.1,-0.6,-1.3$ and $-2.0 \mathrm{~g}$ during the first sub-period, $-0.2,-0.6,-1.3$ and $-2.4 \mathrm{~g}$ during the second sub-period, and $-0.1,-0.6,-1.3$ and $-1.9 \mathrm{~g}$ during the total period, respectively. The significant effect of OEB level on liveweight gain, without an effect on feed intake resulted in a different conversion of DM and NEF during the initial sub-period. Only crude protein conversion was altered during the second sub-period, whereas the differences were not significant during the total period (Table 5). Intake per $\mathrm{kg}$ carcass gain, assuming an initial dressing percentage of 59, resulted in a worse conversion of DM, DVE and NEF when the OEB level decreased from -2 to $-22 \mathrm{~g} \mathrm{~kg}^{-1} \mathrm{DM}$, raising up to 10,8 and $10 \%$, respectively, while crude protein conversion was improved by $9 \%$ in comparison with $\mathrm{OEB}=-2 \mathrm{~g} \mathrm{~kg}^{-1} \mathrm{DM}$.

BUN was significantly decreased when the OEB level decreased. It amounted to 93.3, 90.5, 76.5 and $60.5( \pm 18.8) \mathrm{mg}$ per 1., respectively, after 61 days, with 93.3 and 90.5 being different from $60.5(P<0.05)$. Values after 145 days were higher than after 61 days, and averaged $102.5,101.7,72.3$ and $62.0( \pm 18.4) \mathrm{mg}$ per 1. , respectively, with 102.5 and 101.7 being higher than 72.3 and $62.0(P<0.05)$.

A lower OEB level resulted in a non-significant reduction of the cold carcass weight $(P>0.05)$. There was also a non-significant reduction of the dressing percentage, whereas the SEUROP conformation score was different between -2 and $-22 \mathrm{~g}$ OEB kg-1 DM (Table 6). Carcass composition was not modified by OEB level, except for the percentage of bone. 
Table 4. Effect of dietary OEB level on feed intake.

\begin{tabular}{|c|c|c|c|c|c|}
\hline & \multicolumn{4}{|c|}{ Dietary OEB level ( $\left.\mathrm{g} \mathrm{kg}^{-1} \mathrm{DM}\right)$} & \multirow[t]{2}{*}{ Pooled s.e. } \\
\hline & -2 & -7 & -16 & -22 & \\
\hline \multicolumn{6}{|l|}{ 1-84 days } \\
\hline Concentrate (kg) & 3.43 & 3.34 & 3.31 & 3.41 & 0.33 \\
\hline Maize silage (kg) & 16.31 & 15.87 & 15.82 & 16.00 & 2.17 \\
\hline Dry matter $(\mathrm{kg})$ & 8.59 & 8.35 & 8.32 & 8.47 & 0.83 \\
\hline $\mathrm{NEF}(\mathrm{MJ})$ & 51.37 & 50.04 & 50.09 & 50.78 & 10.02 \\
\hline Crude protein $(\mathrm{kg})$ & $1.17^{\mathrm{a}}$ & $1.08^{\mathrm{ab}}$ & $1.02^{\mathrm{b}}$ & $0.96^{\mathrm{b}}$ & 0.10 \\
\hline DVE (kg) & 0.70 & 0.68 & 0.69 & 0.68 & 0.07 \\
\hline OEB (kg) & $-0.01^{\mathrm{a}}$ & $-0.06^{\mathrm{b}}$ & $-0.13^{\mathrm{c}}$ & $-0.19^{d}$ & 0.06 \\
\hline \multicolumn{6}{|l|}{ 85th day - end } \\
\hline Concentrate $(\mathrm{kg})$ & 3.64 & 3.50 & 3.63 & 3.58 & 0.23 \\
\hline Maize silage (kg) & 17.21 & 16.62 & 17.16 & 17.02 & 2.48 \\
\hline Dry matter $(\mathrm{kg})$ & 9.19 & 8.86 & 9.18 & 9.08 & 0.59 \\
\hline NEF (MJ) & 55.85 & 54.10 & 56.09 & 55.46 & 11.11 \\
\hline Crude protein $(\mathrm{kg})$ & $1.23^{\mathrm{a}}$ & $1.14^{\mathrm{ab}}$ & $1.11^{\mathrm{bc}}$ & $1.01^{\mathrm{c}}$ & 0.09 \\
\hline DVE $(\mathrm{kg})$ & 0.74 & 0.72 & 0.75 & 0.72 & 0.06 \\
\hline OEB (kg) & $-0.02^{\mathrm{a}}$ & $-0.07^{\mathrm{b}}$ & $-0.15^{\mathrm{c}}$ & $-0.21^{\mathrm{d}}$ & 0.02 \\
\hline \multicolumn{6}{|l|}{ Total period } \\
\hline Concentrate (kg) & 3.54 & 3.42 & 3.48 & 3.50 & 0.23 \\
\hline Maize silage (kg) & 16.78 & 16.26 & 16.52 & 16.53 & 2.19 \\
\hline Dry matter $(\mathrm{kg})$ & 8.90 & 8.62 & 8.77 & 8.79 & 0.60 \\
\hline $\mathrm{NEF}(\mathrm{MJ})$ & 53.72 & 52.15 & 53.21 & 53.23 & 10.32 \\
\hline Crude protein $(\mathrm{kg})$ & $1.20^{\mathrm{a}}$ & $1.11^{\mathrm{ab}}$ & $1.06^{\mathrm{bc}}$ & $0.99^{\mathrm{c}}$ & 0.08 \\
\hline DVE $(\mathrm{kg})$ & 0.72 & 0.70 & 0.72 & 0.70 & 0.06 \\
\hline OEB (kg) & $-0.02^{\mathrm{a}}$ & $-0.06^{\mathrm{b}}$ & $-0.14^{\mathrm{c}}$ & $-0.20^{\mathrm{d}}$ & 0.02 \\
\hline
\end{tabular}

${ }^{\text {abcd }}$ Values without or with the same superscripts are not significantly different $(P>0.05)$.

\section{Digestibility and rumen fermentation experiment}

The digestibility coefficients of the 4 diets are given in Table 7. OEB level did not affect the digestibility of most diet components. Only the apparent protein digestibility was decreased when the OEB level was reduced, probably as a result of the relative increase of endogenous protein.

The OEB level did neither affect $\mathrm{pH}$ nor the total amount and the individual concentration of VFA in the rumen fluid (Table 8). Ammonia level was reduced when the OEB level decreased, but only $7 \mathrm{hr}$ postprandial.

\section{Discussion}

It is well known that the protein content of the diet can exert an influence on the animal performance (De Boer \& Hamm, 1977; Boucqué et al., 1984; Fiems et al., 1995). However, the dietary protein content, expressed as DVE, was similar for the 
Table 5. Effect of dietary OEB level on feed conversion.

\begin{tabular}{|c|c|c|c|c|c|}
\hline & \multicolumn{4}{|c|}{ Dietary OEB level ( $\left.\mathrm{g} \mathrm{kg}^{-1} \mathrm{DM}\right)$} & \multirow[t]{2}{*}{ Pooled s.e. } \\
\hline & -2 & -7 & -16 & -22 & \\
\hline \multicolumn{6}{|l|}{ 1-84 days } \\
\hline Dry matter (kg) & $5.48^{\mathrm{a}}$ & $5.66^{\mathrm{ab}}$ & $5.58^{\mathrm{ab}}$ & $6.10^{\mathrm{b}}$ & 0.40 \\
\hline $\mathrm{NEF}(\mathrm{MJ})$ & $32.79^{a}$ & $33.93^{\mathrm{ab}}$ & $33.58^{\mathrm{ab}}$ & $36.55^{\mathrm{b}}$ & 5.02 \\
\hline Crude protein $(\mathrm{kg})$ & 0.75 & 0.74 & 0.68 & 0.69 & 0.06 \\
\hline $\operatorname{DVE}(\mathrm{kg})$ & 0.45 & 0.46 & 0.46 & 0.49 & 0.03 \\
\hline \multicolumn{6}{|l|}{ 85th day - end } \\
\hline Dry matter (kg) & 7.38 & 7.09 & 7.04 & 7.24 & 1.45 \\
\hline $\mathrm{NEF}(\mathrm{MJ})$ & 44.87 & 43.31 & 43.02 & 44.21 & 10.52 \\
\hline Crude protein $(\mathrm{kg})$ & $0.98^{\mathrm{a}}$ & $0.91^{\mathrm{ab}}$ & $0.85^{\mathrm{b}}$ & $0.81^{\mathrm{b}}$ & 0.15 \\
\hline DVE $(k g)$ & 0.60 & 0.57 & 0.57 & 0.58 & 0.10 \\
\hline \multicolumn{6}{|l|}{ Total period } \\
\hline Dry matter (kg) & 6.37 & 6.35 & 6.29 & 6.67 & 0.65 \\
\hline $\mathrm{NEF}(\mathrm{MJ})$ & 38.42 & 38.41 & 38.16 & 40.35 & 6.62 \\
\hline Crude protein $(\mathrm{kg})$ & 0.86 & 0.82 & 0.76 & 0.75 & 0.07 \\
\hline DVE $(\mathrm{kg})$ & 0.52 & 0.52 & 0.52 & 0.53 & 0.04 \\
\hline
\end{tabular}

abcd Values without or with the same superscripts are not significantly different $(P>0.05)$.

different treatments, but the protein quality was different. There was a gradual reduction of the protein degradability beside a reduced crude protein content, which was reflected in a decreased OEB level. A decreased OEB level reduced the daily LW gain during the initial months of the finishing period (LW interval $375-500 \mathrm{~kg}$ ). Afterwards, no effect from the OEB level was observed for $-22 \mathrm{~g} \mathrm{OEB}$, or even a slight compensatory gain was realised for -7 and $-16 \mathrm{~g}$ OEB. This may be provoked by more nitrogen available for recycling (higher BUN) and more energy available for

Table 6. Effect of dietary OEB level on carcass characteristics.

\begin{tabular}{|c|c|c|c|c|c|}
\hline & \multicolumn{4}{|c|}{ Dietary OEB level ( $\left.\mathrm{g} \mathrm{kg}^{-1} \mathrm{DM}\right)$} & \multirow[t]{2}{*}{ Pooled s.e. } \\
\hline & -2 & -7 & -16 & -22 & \\
\hline Slaughter weight (kg) & 620.3 & 600.7 & 607.3 & 593.9 & 41.9 \\
\hline Cold carcass weight $(\mathrm{kg})$ & 386.9 & 374.3 & 380.5 & 369.6 & 31.3 \\
\hline Dressing $(\%)$ & 63.4 & 62.3 & 62.7 & 62.2 & 1.9 \\
\hline \multicolumn{6}{|l|}{ SEUROP-classification } \\
\hline Conformation & $11.5^{\mathrm{a}}$ & $11.1^{\mathrm{ab}}$ & $10.9^{\mathrm{ab}}$ & $10.5^{b}$ & 1.5 \\
\hline Fat covering & 7.2 & 7.6 & 7.4 & 7.0 & 1.3 \\
\hline \multicolumn{6}{|l|}{ Carcass composition $(\%)$} \\
\hline Meat & 67.0 & 66.3 & 66.4 & 66.2 & 2.6 \\
\hline Fat & 19.3 & 20.6 & 20.4 & 20.1 & 3.1 \\
\hline Bone & $13.7^{\mathrm{a}}$ & $13.1^{\mathrm{b}}$ & $13.2^{\mathrm{ab}}$ & $13.7^{\mathrm{a}}$ & 1.2 \\
\hline
\end{tabular}

ab Values without or with the same superscripts are not significantly different $(P>0.05)$. 
Table 7. Effect of dietary OEB level on digestibility in sheep.

\begin{tabular}{llllll}
\hline & \multicolumn{2}{l}{ Dietary OEB level $\left(\mathrm{g} \mathrm{kg}^{-1} \mathrm{DM}\right)$} & \multirow{2}{*}{ Pooled s.e. } \\
\cline { 2 - 5 } & -2 & -7 & -16 & -22 & \\
\cline { 2 - 5 } Dry matter & & & & & \\
Organic matter & 77.0 & 77.7 & 77.3 & 77.2 & 1.9 \\
Crude protein & 80.1 & 80.6 & 80.4 & 80.3 & 1.9 \\
Ether extract & $74.2^{\mathrm{a}}$ & $73.2^{\mathrm{a}}$ & $71.6^{\mathrm{a}}$ & $68.9^{\mathrm{b}}$ & 3.8 \\
Crude fibre & 86.7 & 86.9 & 86.6 & 86.5 & 2.5 \\
N-free extract & 67.3 & 69.5 & 69.0 & 70.2 & 4.4 \\
Gross energy & 84.2 & 84.8 & 84.9 & 84.7 & 1.2 \\
\hline
\end{tabular}

${ }^{\mathrm{ab}}$ Values without or with the same superscripts are not significantly different $(P>0.05)$.

microbial protein synthesis and a lower DVE requirement in heavier animals, which is in agreement with a larger tolerable OEB-lack in heavier animals, as proposed by Van Vliet et al. (1994). It is possible that the slight compensatory gain during the second sub-period was due to the fact that the OEB and DVE levels were maintained during the total period. In an experiment of Heeres-van der Tol \& Plomp (1996) there was a simultanous decrease in OEB (from 0 to $-22 \mathrm{~g} \mathrm{~kg}^{-1} \mathrm{DM}$ ) and DVE (from 83 to $62 \mathrm{~g} \mathrm{~kg}^{-1} \mathrm{DM}$ ), and no compensatory effect was observed. It is not clear why there was no compensatory gain for the $-22 \mathrm{~g} \mathrm{OEB} \mathrm{kg}^{-1} \mathrm{DM}$ in comparison with $-16 \mathrm{~g}$

Table 8. Effect of dietary OEB level on rumen fermentation characteristics of sheep.

\begin{tabular}{|c|c|c|c|c|c|}
\hline & \multicolumn{4}{|c|}{ Dietary OEB level ( $\left.\mathrm{g} \mathrm{kg}^{-1} \mathrm{DM}\right)$} & \multirow[t]{2}{*}{ Pooled s.e. } \\
\hline & -2 & -7 & -16 & -22 & \\
\hline Volatile fatty acids (VFA, mmol/L) & 96.6 & 95.8 & 98.7 & 95.7 & 1.7 \\
\hline \multicolumn{6}{|l|}{ Molar $\%$ of VFA } \\
\hline Acetic acid & 63.6 & 64.8 & 62.8 & 63.0 & 3.6 \\
\hline Propionic acid & 18.9 & 18.6 & 20.6 & 21.4 & 4.5 \\
\hline Butyric acid & 14.3 & 14.0 & 14.2 & 13.1 & 2.7 \\
\hline Isobutyric Acid & 0.7 & 0.7 & 0.6 & 0.5 & 0.2 \\
\hline 2-Methylbutyric acid & 0.5 & 0.4 & 0.4 & 0.4 & 0.4 \\
\hline Valeric acid & 1.3 & 1.2 & 1.1 & 1.2 & 1.2 \\
\hline Isovaleric acid & 0.6 & 0.5 & 0.4 & 0.4 & 0.2 \\
\hline \multicolumn{6}{|l|}{ Ammonia (mg/L) } \\
\hline before feeding & 32.8 & 31.1 & 29.5 & 27.3 & 6.5 \\
\hline $3.5 \mathrm{hr}$ postprandial & 36.3 & 34.1 & 32.7 & 31.1 & 7.6 \\
\hline $7 \mathrm{hr}$ postprandial & $27.3^{\mathrm{a}}$ & $26.9^{\mathrm{a}}$ & $24.5^{\mathrm{ab}}$ & $18.5^{\mathrm{b}}$ & 6.6 \\
\hline \multicolumn{6}{|l|}{$p H$} \\
\hline before feeding & 6.96 & 6.91 & 6.99 & 7.06 & 0.20 \\
\hline $3.5 \mathrm{hr}$ postprandial & 6.12 & 6.19 & 6.18 & 6.10 & 0.20 \\
\hline $7 \mathrm{hr}$ postprandial & 6.61 & 6.64 & 6.61 & 6.61 & 0.20 \\
\hline
\end{tabular}

${ }^{\text {ab }}$ Values without or with the same superscripts are not significantly different $(P>0.05)$. 
Table 9. Verification of tolerable OEB level.

\begin{tabular}{|c|c|c|c|c|}
\hline & \multicolumn{4}{|c|}{ Dietary OEB level ( $\left.\mathrm{g} \mathrm{kg}^{-1} \mathrm{DM}\right)$} \\
\hline & -2 & -7 & -16 & -22 \\
\hline \multicolumn{5}{|l|}{ 1-84 days } \\
\hline Daily DVE intake (g) & 703 & 681 & 688 & 682 \\
\hline Daily OEB lack (g) & 8 & 57 & 128 & 186 \\
\hline DVE requirement $^{\mathrm{a}}(\mathrm{g})$ & 569 & 545 & 549 & 522 \\
\hline \multicolumn{5}{|l|}{ Tolerable OEB-lack (g) } \\
\hline Equation $1^{\mathrm{b}}$ & 48 & 47 & 47 & 46 \\
\hline Equation $2^{\mathrm{c}}$ & 206 & 209 & 214 & 246 \\
\hline \multicolumn{5}{|l|}{ 84th day-end } \\
\hline Daily DVE intake (g) & 741 & 716 & 749 & 723 \\
\hline Daily OEB lack (g) & 21 & 65 & 145 & 205 \\
\hline DVE requirement $^{\mathrm{a}}(\mathrm{g})$ & 555 & 563 & 565 & 549 \\
\hline \multicolumn{5}{|l|}{ Tolerable OEB-lack (g) } \\
\hline Equation $1^{\mathrm{b}}$ & 79 & 77 & 78 & 75 \\
\hline Equation $2^{\mathrm{c}}$ & 286 & 235 & 283 & 268 \\
\hline
\end{tabular}

a Based on LW and LW gain as mentioned in Table 3

b $(\mathrm{LW}-250) * 0.25$

${ }^{\mathrm{c}}$ DVE-intake - DVE requirement)/0.65.

OEB $\mathrm{kg}^{-1}$ DM. For both treatments BUN was hardly different between the second part of the experiment (72.3 and $62.0 \mathrm{mg} \mathrm{l}^{-1}$ ) compared to the first part (76.5 and $60.5 \mathrm{mg} \mathrm{l}^{-1}$ ). Higher BUN-values were obtained with diets containing a higher OEB level. They are generally reflective of an increased protein intake (Preston et al., 1965; Leibholz, 1970). Higher BUN-values were also obtained in heavier animals, suggesting that additional protein was utilised less efficiently in older animals (Fiems et al., 1997). The non-detrimental effect of OEB levels of -7 and -16 corresponded with a dietary crude protein level of 12.9 and $12.1 \%$. This is in agreement with a crude protein level of $12 \%$, previously recommended by Boucqué et al. (1980).

Feed intake may be affected by protein levels. Ketelaars \& Tolkamp (1992) showed that the range of dietary protein content over which a positive effect is seen, far exceeds values that may limit ruminal microbial fermentation. The crude protein levels in this experiment ranged between 112 and $135 \mathrm{~g}$ per $\mathrm{kg} \mathrm{DM}$, but did not affect DM and NEF intake.

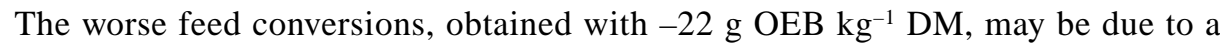
lower LW gain, resulting in a relatively higher maintenance requirement. We assume a negligible effect of OEB level on the energy value of the diets, as the organic matter digestibility and the concentration of VFA in the rumen of sheep were not different.

Lower OEB levels and ditto crude protein levels did not result in a reduced dressing proportion. However, the differences were significant when dressing was adjusted for the lower carcass weight. It is well known that dressing is positively related 


\section{L.O. FIEMS ET AL.}

with carcass weight (Van De Voorde \& Verbeke, 1979). Lower dietary protein concentrations also decreased the dressing proportion in experiments of Boucqué et al. (1980 and 1984). On the other hand, meat content in the carcass was not modified. Nevertheless, results of Berge et al. (1993) have shown that muscle content in the carcass can be altered by different dietary protein levels.

An OEB lack can be tolerated, assuming that the daily OEB lack is smaller than the smallest value from two equations: ' $(\mathrm{LW}-250) * 0.25$ ' on the one hand, and '(DVE-intake - DVE-requirement)/0.65', on the other hand (Van Vliet et al., 1994). Using these equations and the mean LW and feed intake during the two sub-periods, we can calculate the maximum tolerable OEB lack (see Table 9). Based on a similar LW gain and feed conversion in the third treatment group as in the first and the second treatment group during the first part of the experiment (see Tables 3 and 5, respectively), we conclude that the tolerable OEB lack contains a safety margin, mainly because the first criterion is too restrictive. Obviously, an OEB value of $-16 \mathrm{~g} \mathrm{~kg}^{-1}$ DM is still acceptable with regard to animal performance and carcass quality.

At a similar DVE-content, the reductions in OEB level only decreased apparent protein digestibility. Tritschler et al. (1984) also found that crude protein only affected protein digestibility. However, in a previous study we found that a lower protein level decreased digestibility of all feed components, except crude fibre and fat (Fiems et al., 1997). Similar to DM and organic matter digestibility in the present experiment, ruminal VFA-concentration and molar percentages were neither changed by OEB level, suggesting a comparable content of fermentable organic matter in the diets. Jones et al. (1973) reported a different VFA-concentration and a different molar percent of acetate for different dietary protein levels. According to Mehrez et al. (1977) a maximum rate of fermentation occurs at a minimal ammonia concentration of $235 \mathrm{mg} / \mathrm{l}$. rumen fluid. Only the rumen fluid from the lowest OEB level, sampled $7 \mathrm{hr}$ after feeding, was below this threshold and was lower than in the two diets with the highest OEB levels. The fact that we did not find an influence of OEB level on rumen $\mathrm{pH}$ was in accordance with the results of Jones et al. (1973). Regarding nitrogen recycling, the transposition of results obtained in adult sheep to growing-finishing bulls must be interpreted with care, as the protein requirements in both types of animals are different.

It can be concluded from this experiment that a negative OEB-value between -7 and $-16 \mathrm{~g} \mathrm{~kg}^{-1}$ dietary DM, beside an overfeeding of DVE (80 $\mathrm{g}$ per $\mathrm{kg}$ dietary DM), is still acceptable during a LW-range from 375 to $620 \mathrm{~kg}$. This also means that the amount of nitrogen available in the rumen is more restrictive in the Dutch than in the French protein system.

\section{Acknowledgement}

The authors are grateful to Mrs. N. De Paepe and Mrs. L. Roels, and Messrs. R. Coens and R. Van Herreweghe from the Section Cattle Husbandry of the department for their skilled technical assistance. 


\section{References}

Anonymous, 1981. Classification scheme for beef carcass classes. Official Journal of the European Communities. Council Regulations No. 1208/81 and 2930/81.

Anonymous, 1988. Alimentation des bovins, ovins et caprins. Institut National de la Recherche Agronomique, Paris, $471 \mathrm{pp}$.

Anonymous, 1991. Protein evaluation for ruminants: The DVE-system. (In Dutch). CVB-series No. 7, Centraal Veevoederbureau, Lelystad, $53 \mathrm{pp}$.

Anonymous, 1992. Merckotest 3334, Diagnostica Merck. Directions for use. Clinical Chemistry, Darmstadt, p. 171.

Anonymous, 1994. Chemical composition, digestibility and feeding value of feedstuffs (In Dutch). Centraal Veevoederbureau, Lelystad, $453 \mathrm{pp}$.

Anonymous, 1997. Cat. No. 1, 1825, Supelco Inc., Bellafonte PA, 672 pp.

Berge, P., J. Culioli, M. Renerre, C. Touraille, D. Micol, \& Y. Geay, 1993. Effect of feed protein on carcass composition and meat quality in steers. Meat Science 35: 79-92.

Boucqué, Ch.V., L.O. Fiems, B.G. Cottyn \& F.X. Buysse, 1980. Belgian energy and protein feeding standards for growing and finishing cattle. Annales de Zootechnie 29, Suppl.: 383-387.

Boucqué, Ch.V., L.O. Fiems, B.G. Cottyn \& Buysse, F.X. 1984. Besoins en protéines des taureaux culards au cours de la période de finition. Revue de l'Agriculture 37: 661-670.

De Boer, F. \& G.G.H. Hamm, 1977. Protein requirements and non-protein nitrogen supplementation in fattening bulls. Recent developments in the use of new sources of protein and non-protein nitrogen for ruminants. Pergamon Press, Oxford, pp. 145-156.

De Boever, J.L., J.M. Vanacker, D.F. Bogaerts \& Ch.V. Boucqué, 1995. Protein evaluation of cattle compound feeds: comparison of in sacco measurements and tabular values. Netherlands Journal of Agricultural Science 43: 297-311.

De Boever, J.L., B.G. Cottyn, D.L. De Brabander, J.M. Vanacker \& Ch.V. Boucqué, 1998. Equations to predict digestibility and energy value of grass silages, maize silages, grass hays, compound feeds and raw materials for cattle. Nutrition Abstract Reviews (in press).

Fiems, L.O., D.F. Bogaerts, B.G. Cottyn, E. Decuypere \& Ch.V. Boucqué, 1995. Effect of protein level on performance, carcass and meat quality, hormone levels and nitrogen balance of finishing Belgian white-blue double-muscled bulls. Journal of Animal Physiology and Animal Nutrition 73: 213-223.

Fiems, L.O., B.G. Cottyn, Ch.V. Boucqué, D.F. Bogaerts, C. Van Eenaeme \& J.M. Vanacker, 1997. Effect of beef type, body weight and dietary protein content on voluntary feed intake, digestibility, blood and urine metabolites and nitrogen retention. Journal of Animal Physiology and Animal Nutrition 77: 1-9.

Fiems, L.O., R.J. Moermans, Ch.V. Boucqué, B.G. Cottyn \& S. De Campeneere, 1999. Voluntary feed intake in dual-purpose and double-muscled Belgian White-Blue bulls. Proc. 5th Zodiac symposium on 'Regulation of feed intake', Wageningen, 22-24 April 1998 (in press).

Heeres-van der Tol, J.J. \& M. Plomp, 1996. Degradable protein balance in rations for beef bulls (In Dutch). Publication 119, (PR), Praktijkonderzoek Rundvee, Schapen en Paarden Lelystad, 17 pp.

Jones, G.M., A. Cecyre \& J.-M. Gaudreau, 1973. Effects of dietary protein and cellulose content of semipurified diets on voluntary feed intake and digestibility by sheep. Canadian Journal of Animal Science 53: 445-454.

Ketelaars, J.J.M.H. \& B.J. Tolkamp, 1992. Towards a new theory of feed intake regulation in ruminants 1. Causes of differences in voluntary feed intake: critique of current views. Livestock Production Science 30: 269-296.

Leibholz, J., 1970. The effect of starvation and low nitrogen intakes on the concentrations of free amino acids in the blood plasma and on the nitrogen metabolism in sheep. Australian Journal of Agricultural Research 21:723-734.

Madsen, J., 1985. The basis for the proposed Nordic protein evaluation system for ruminants. The AATPBV system. Acta Agriculturae Scandinavica 25, Suppl.: 9-20.

Mehrez, A.Z., E.R. Ørskov \& I. McDonald, 1977. Rates of rumen fermentation in relation to ammonia concentration. The British Journal of Nutrition 38: 447-443.

Preston, R.L., D.D. Schnakenberg \& W.H. Pfander, 1965. Protein utilization in ruminants I. Blood urea nitrogen as affected by protein intake. Journal of Nutrition 86: 281-288. 


\section{L.O. FIEMS ET AL.}

Tamminga, S., W.M. van Straalen, A.P.J. Subnel, R.G.M. Meijer, A. Steg \& Wever, C.J.G. 1994. The Dutch protein evaluation system: the DVE/OEB-system. Livestock Production Science 40: 139-155.

Tritschler, J.P., R.L. Shirley \& J.E. Bertrand, 1984. Tissue protein and energy deposition in steers fed isocaloric diets with different levels of nitrogen. Journal of Animal Science 58: 444-451.

Van De Voorde, G. \& R. Verbeke, 1979. La conformation et les caractéristiques d'abattage de taureaux. Revue de l'Agriculture 32: 117-128.

Van Es, A.J.H. 1977. Feed evaluation for ruminants. I. The system in use from May 1977 onwards in The Netherlands. Livestock Production Science 5: 331-345.

Van Vliet, J., J.J. Heeres-van der Tol \& M.C. Blok, 1994. Revision of energy and protein requirements for beef bulls (In Dutch). CVB-documentatierapport nr. 11, Centraal Veevoederbureau, Lelystad, 60 pp.

Verbeke, R. \& G. Van De Voorde, 1978. Détermination de la composition de demi-carcasses de bovins par la dissection d'une seule côte. Revue de l'Agriculture 31: 875-880.

Voigt, J. \& H. Steger, 1967. Zur quantitativen Bestimmung von Ammoniak, Harnstoff und Ketokörpern in biologischem Material mit Hilfe eines modifizierten Mikrodiffusionsgefässes. Archiv für Tiererährung 17: 289-293. 